\section{The business of giving}

\author{
W. F. Bynum
}

The Circult Riders: Rockefeller Money and the Rise of Modern Sclence. By Gerald Jonas. W. W. Norton: 1989. Pp.430. \$22.95.

THERE are some people who would argue that it is at least as difficult to give away money wisely as it is to make it in the first place. Most scientists neither make nor give away large sums, but few experimentalists could work nowadays without somebody, from somewhere, providing them with a good deal more than their monthly pay cheques. Equipment, materials and technical assistance are expensive, and the business of grantsmanship looms larger for academic scientists than for their colleagues in arts or social sciences faculties.

Religious, educational, social, moral and health-care philanthropy have been around for centuries. Scientific philanthropy is barely a century old, but modern science has been indelibly shaped by it. The line between philanthropy and patronage is a fine one, but if we identify the first with the private sector and the second with the state, or public sector, some significant differences between the United States and Britain emerge. The relatively early establishment of the Research Councils - beginning with the forerunner of the Medical Research Council before the First World War ensured that the state played a dominant role in research support in Britain. This is still the case even if thatcherite policies have made the private research charities more important (the annual budget of the Wellcome Trust, Britain's largest private medical research charity, is now almost as large as that of the Medical Research Council). In the United States, however, before the Second World War the federal government's commitment to scientific and medical research was dwarfed by that of the big private foundations bearing the names of the industrialists (or robber barons) whose fortunes had created them. In the past few decades, the budget of the National Institutes of Health has put into the shade even that of the largest American foundations, which in turn are gigantic when compared with the best that Britain can muster.

The foundations, endowed by selfmade men such as Andrew Carnegie and John D. Rockefeller Sr, marked by their very magnitude a new epoch in the history of philanthropy. They were in the wholesale end of the charity business and their massive scale meant that their founders could not possibly personally oversee

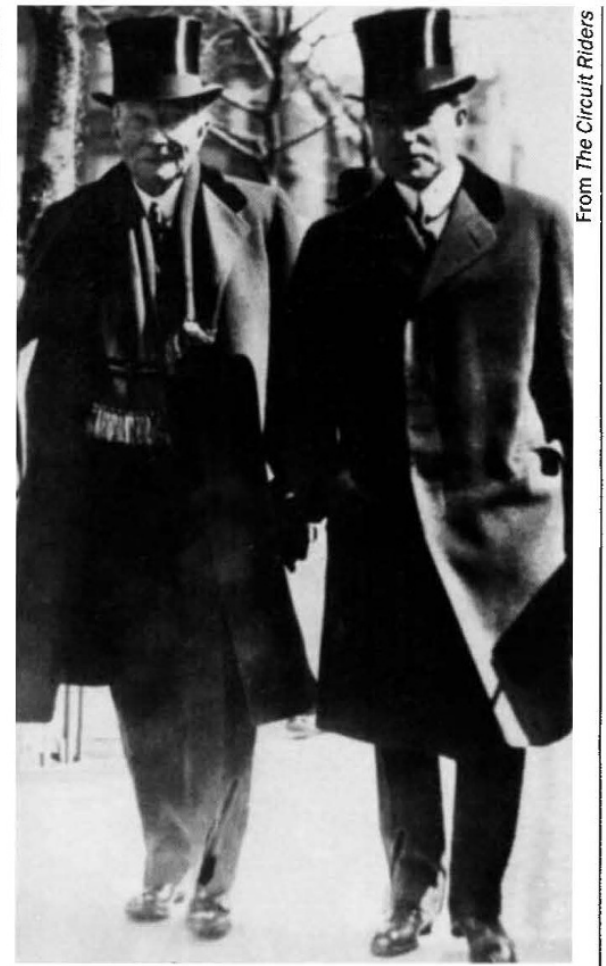

A couple of swells - the J. D. Rockefellers senior and junior in 1921.

giving away every penny of the largesse. Carnegie tried hard to do so, gradually withdrawing and eventually retiring from business (his was steel) to devote himself totally to his various philanthropic concerns, including education, public libraries and world peace. But even he had to rely on advisors, especially after scientific research was added to his charitable portfolio. Rockefeller (his money came from oil) was always more aloof, confining himself mostly to the getting of wealth and allowing a new breed of individuals who called themselves 'philanthropoids' - to oversee its distribution.

Philanthropoids are people who earn their living by giving away someone else's money, and it was they who insisted that their jobs were not necessarily easy; the biography of Alan Gregg, one of Rockefeller's philanthropoids, was entitled The Difficult Art of Giving. Rockefeller's philanthropic employees were convinced, however, that he had a moral duty to give away a substantial proportion of his enormous fortune: "You must distribute it faster than it grows! If you do not, it will crush you and your children and your children's children", Frederick Gates cautioned him in 1905. Rockefeller's descendants have not wanted for the odd copper to spend on themselves, but the founder of the clan did establish a pattern of giving which suggests he heeded the advice of Gates and his other advisors. Carnegie and Rockefeller gave away $\$ 850$ million during their lifetimes, a sum which must be put into the buying-power perspective of their deaths in 1919 and 1939 respectively. (Their combined ages of 181 remind us that they had plenty of time to give it away, and also that they did not seem to suffer from any diseases of guilt.)

Gerald Jonas's volume assesses, as its subtitle makes clear, the effect of Rockefeller's legacy on modern science. Its sideways glances at Carnegie are incidental, but appropriate, because the two magnates saw themselves as philanthropic rivals. Until relatively late in his life, Carnegie devoted much of his money to fairly traditional 'missionary' activities: trying to make ordinary individuals healthier, or happier, or better educated through things like schools and libraries. There was a missionary side to Rockefeller's endeavours as well: reconstruction during and after the First World War, or the campaign to eradicate hookworm in the American South. Missionary work simply applied existing knowledge or helped rebuild what war had destroyed.

Gradually, Rockefeller became convinced that the motto of his foundation ("Towards the betterment of mankind") was best achieved through the creation of new knowledge, above all in science and medicine. Ironies abound: it was Gates, a Baptist minister, who read William Osler's Principles and Practice of Medicine, with its realistic, pessimistic account of medical therapy, and persuaded Rockefeller that medical research was a good thing. One result was the Rockefeller Institute (now Rockefeller University). When Rockefeller established his institute in 1901, his personal medical care was being overseen by a homoeopathist. Rockefeller shared Gates's Baptist faith: one result was a massive channelling of money which transformed an insignificant Baptist establishment called the University of Chicago into a great secular research-orientated university.

The foundation's emphasis on scientific and medical research inevitably meant more of Rockefeller's philanthropoids were scientists or doctors themselves, or men such as the philosopher Wickliffe Rose who had absorbed the gospel of science. Warren Weaver, a physicist, was instrumental in Rockefeller support for a discipline which Weaver himself first called "molecular biology", and the bacteriologist Selskar M. (Mike) Gunn kept Rockefeller's European operations going for a crucial decade.

In the nineteenth century the internationalism of science had been effectively espoused, and Rockefeller's philanthropoids shared this ethos. This meant creating schools of public health throughout the world, or giving money for academic medicine in Britain and physics research in Germany, or helping scientific refugees from Nazi Germany, or supporting Howard Florey's penicillin work, were as much in their brief as the considerable sums which stayed behind for the emerging scientific community in the United States. 
Except for a couple of summary chapters, Jonas's account ends just after the Second World War. It is thus confined to the 'circuit riding' period of Rockefeller philanthropy, before the modern peerreview system emerged. Like the frontier Methodist preachers riding their circuits, Rockefeller's philanthropoids travelled incessantly in search of worthy recipients. Officials at the top of the Rockefeller balance, they seem to have used reasonably. Jonas (a staff writer for The New Yorker) does not attempt to tell the whole story. There is little on the Rockefeller hierarchy had enormous power which, on

Institute itself, or on the endowment of the schools of public health, and rather too much on Florey and penicillin. But he is good on the gradual shift from bricks and mortar philanthropy to more support for individual scientists, on the development of informal networks of advisors, and on the personal contributions of key philanthropoids. Jonas gives us an apposite portrait of modern science in the making, but still not fully made.

W.F. Bynum is at the Wellcome Institute for the History of Medicine, 183 Euston Road, London NW1 2BP, UK

\section{Mad for money}

\section{Daniel S. Greenberg}

Ungulded Missiles: How America Buys Its Weapons. By Fen Hampson. W.W. Norton: 1989. Pp.348. \$19.95.

THE military establishment in the United States is often depicted as a rogue enterprise that thrives against the will of the body politic. President Dwight Eisenhower suggested that conception in his valedictory warning against the "militaryindustrial complex". Numerous works, academic and journalistic, have taken up the theme, exposing the wily collusions of the Pentagon and its political and industrial collaborators.

Hampson, a professor of international relations at Carleton University, Ottawa, carries on the tradition by applying economic analysis and game theory to a halfdozen of the military's grandest research and procurement extravaganzas - the B-1 bomber, the Trident missile system, the MX missile, the air-launched cruise missile, the Strategic Defense Initiative and the Abrams tank (covered in a chapter by a colleague, N. Swales). Referring to and quoting heavily from numerous works by others, Hampson observes that these systems have survived years - even decades - of political opposition, premature obsolescence and cost increases vastly beyond the original estimates. Except in rare instances, weapons systems that have passed the research stage have proven to be invulnerable to termination, whether for political or technical reasons. Why?

The answer, says Hampson, is that the military services compete for budgets up to a point, but their rivalries are "marked by 'competitive cooperative' behavior akin to that noted by economists in oligopolistic settings and by game theorists in iterated or repetitive games" (p. 301). Specifically, the sacred systems of each service - the Navy's carriers, the Army's tanks, and the Air Force's missiles and manned aircraft - are out of bounds for

serious challenge by the others.

So much for the collusion of the military services. What of their presumed political masters in Congress? "Congress almost never addresses the fundamental question 'Should we fund this program?' Rather, the question is 'How much?' Once we understand the logic of this process it becomes easier to see why weapon programs rarely die at the hands of Congress" (p. 47). One reason they don't die is the high 'pork' value of defence spending, as typified by the distribution of B-1 bomber subcontracts to 48 states. When a challenge to the programme's budget developed, the Air Force and its main contractor, Rockwell, roamed Capitol
Hill, with lists of every contract crossreferenced by state, town and Congressman.

And the White House? During eight years of Reagan, it never met a major weapons system it didn't like. But even before Reagan, the champions of big weapons systems rarely encountered effective political opposition. Jimmy Carter, for example, banned the start of production on the B-1. But, as Hampson reports, Carter later lamented that "the enormous B-1 lobbying octopus was still alive and writhing. It would live to fight again after I left the White House" (p.163).

Again and again, the weapons champions have overcome political resistance and even technological good sense to field their systems. Mobility, as a safeguard against a sudden Soviet strike, was a

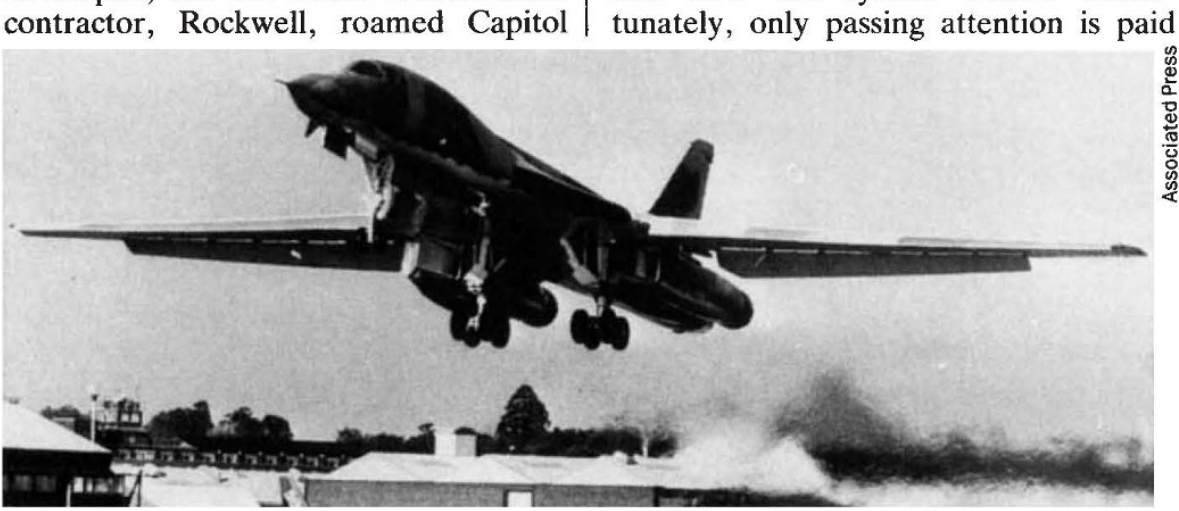

Pork on the wing - the US Air Force B-1 bomber at Farnborough, Britain in 1982.

major rationale for the $\mathrm{MX}$, a missile system that survived 13 years of difficult gestation. Advocates of arms control feared it as a provocative first-strike weapon. And no satisfactory means of moving it about was ever devised. As a last resort, the MX was based in stationary silos originally built for Minuteman missiles. Hampson notes that Carter tolerated the MX's survival "to appease Congressional hardliners who worried that arms control would lull the United States into a false sense of security". $\mathrm{He}$ adds that "Worries about ICBM [intercontinental ballistic missile] vulnerability were all but swept under the rug of political expediency" (p. 143)

From the case studies, Hampson concludes that the military establishment, industrialists and politicians all view the defence budget as a bountiful resource that can accommodate all claimants if none is too greedy. The bargaining process, he explains, "assures rewards or payoffs to all parties from cooperative behavior. A program will therefore not get all of the funds and resources its sponsors want, but, by the same token, it will rarely be killed" (p. 303).

By combining the rogue thesis with game theory and economic analysis, Hampson thus provides useful insights into how the system works. Unfortunately, only passing attention is paid

to a more important and little-explored issue: why is the system tolerated, when, demonstrably, its extravagance and technological obtuseness detract from national security and result in the squandering of resources? What is the fertile ground on which this venerable militarypolitical-industrial complex has thrived for 40 years?

The answer, of course, is the Soviet threat, surely real, but repeatedly manipulated and misrepresented by the 'weaponeers' to undermine opposition and to create a climate of opinion favourable to any weapons system - no matter how foolhardy and expensive. Hampson observes that "Little doubt exists that intelligence and threat assessments are highly politicized assets in weapons programs" (p. 287). He notes, too, that "As the level of resources required by a 